\title{
36. SULFUR CONTENT AND SULFUR ISOTOPES OF BASALTS FROM THE COSTA RICA RIFT (HOLE 504B, DEEP SEA DRILLING PROJECT LEGS 69 AND 70) ${ }^{1}$
}

\author{
Hans-W. Hubberten, Institut für Petrographie und Geochemie der Universität (TH) Karlsruhe, Kaiserstrasse 12, \\ D-7500 Karlsruhe, Federal Republic of Germany
}

\begin{abstract}
About 150 basalt samples from Hole 504B, near the Costa Rica Rift were analyzed for sulfur content and sulfur-isotope composition. The basement in Hole 504B can be divided into an upper part, which has oxidative alteration (274.5 $-550 \mathrm{~m}$ below sea floor), and a lower part, which has nonoxidative alteration (550-835 $\mathrm{m}$ below sea floor) (the interval from 540 to 585 meters actually is transitional). This division is reflected in both the sulfur content and the sulfurisotope composition. Oxidative alteration of basalts by sea water at low temperatures has resulted in a depletion in sulfur in the upper part of the hole (mostly less than $600 \mathrm{ppm} \mathrm{S}$ ) as compared to fresh sulfur-saturated oceanic tholeiites (900-1200 ppm S). High amounts of sulfur in the lower part of the hole are a result of precipitation of secondary pyrite under non-oxidative or weakly oxidative conditions from solutions which dissolved igneous sulfides.

The average sulfur-isotope composition of the primary igneous sulfides is $\delta^{34} \mathrm{~S}=-0.01 \%$, which is close to the assumed mantle sulfur composition $\left(\delta^{34} \mathrm{~S}=0 \%\right.$. Pyrite and sulfate sulfur extracted together in a separate preparation step (as "pyrite-sulfate" sulfur) indicate addition of sea-water sulfate to the upper part of the basalts. The $\delta^{34} \mathrm{~S}$ of secondary pyrite isolated by hand-picking varies between -8.0 and $+5.8 \%$; the "pyrite-sulfate" sulfur $\left(\delta^{34} \mathrm{~S}=-4.8\right.$ to $+10.5 \%$ ), as well as that of the isolated pyrite, may have originated in the precipitation of pyrite from solutions containing sulfur from the dissolution of igneous sulfides, but addition of sulfur transported by hydrothermal solutions cannot be excluded.
\end{abstract}

\section{INTRODUCTION}

Because the degassing of volatiles is inhibited by water pressure, the sulfur content of basalts erupted on deep ocean floors is significantly higher than that of basalts erupted subaerially or in shallow waters (Moore and Fabbi, 1971). The sulfur in submarine basalts occurs in various forms (Czamanske and Moore, 1977; Mathez, 1976): as sulfide globules in glass or the crystalline matrix, as a dissolved constituent in the basaltic glass, as irregular grains of sulfides, and as secondary sulfides coating the walls of vesicles or in veins. Primary sulfates can occur in silicates, depending on the oxygen fugacity of the melt (Schneider, 1970). Basaltic melts normally erupt in a sulfur-saturated or nearly sulfursaturated state (Mathez, 1976). Applying the curve of Mathez (1976) for the relationship between iron and sulfur content in fresh basaltic glass to the material drilled during Legs 69 and 70 at Hole 504B, the sulfur content of these basalts should range from 900 to $1200 \mathrm{ppm}$.

However, Andrews (1979) has shown that during the alteration of basalts by sea water the sulfur will be extracted from the basalts and can then be removed from the system in higher amounts. The 561 meters of basalt cored at Hole 504B $\left(1^{\circ} 14^{\prime} \mathrm{N}\right.$; $83^{\circ} 44^{\prime} \mathrm{W}$, Costa Rica Rift) have partly been intensively altered by circulating waters (Noack et al., this volume; Honnorez et al., this volume). Whereas in the upper 300 meters of the cored basalt column normal oxidative alteration by intruding or circulating sea water at low temperatures occurred, below that level alteration was non-oxidative and was

\footnotetext{
${ }^{1}$ Cann, J. R., Langseth, M. G., Honnorez, J., Von Herzen, R. P., White, S. M., et al., Init. Repts. DSDP, 69: Washington (U.S. Govt. Printing Office).
}

caused by solutions reaching temperatures up to $120^{\circ} \mathrm{C}$ at the bottom of the hole (CRRUST, in press). The two parts of the hole are distinctive not only in appearance (red colors in the upper part; green, dark colors in the lower part) and in alteration petrography (for example, calcite is rare in the lower parts, and pyrite is rare in the upper parts), but also in the chemistry of the basalts. Constituents such as potassium, water, and carbonate, which are used as parameters typical for the alteration of basalts by sea water (Emmermann and Puchelt, 1980), increase in the upper part with progressing alteration; the behavior of water and carbonate is insignificant in the lower part, but potassium never exceeds values typical of absolutely fresh tholeiites (Hubberten et al., this volume; Honnorez et al., this volume). It follows from these considerations that a relation between oxidation and sulfur content should be observed in the upper part of the hole, and the sulfur content in the lower part should give information on its behavior during non-oxidative alteration.

Investigations of the sulfur-isotope composition of primary sulfides in oceanic tholeiites have shown that the sulfur-isotope ratio varies only slightly around the meteoritic value, the zero point of the $\delta$ scale (Kanehira et al., 1973; Grinenko et al., 1975; Sakai et al., 1978; Puchelt and Hubberten, 1980; Hubberten and Puchelt, 1980; Hubberten, in press). Because the Costa Rica Rift basalts are normal oceanic tholeiites (Hubberten et al., this volume), no deviation from the mean value was expected. By investigating the sulfur-isotope composition of the secondary sulfur phases in these basalts (possibly sulfate and subordinate pyrite in the upper part of the hole, abundant pyrite and subordinate sulfate in the lower part), I expected to obtain information about the 
mechanisms responsible for formation of the various sulfur species in the various parts of the hole.

\section{SAMPLE DESCRIPTION}

Fresh and altered samples were selected on the basis of visual observations on board ship for investigation of sulfur contents and isotopes. Three major kinds of lava were encountered in Hole 504B: massive flows (up to 23 $\mathrm{m}$ thick), flow breccias, and highly fractured pillows or sequences of thin flows. The basalts range from aphyric to sparsely to highly olivine-plagioclase-clinopyroxene phyric. The association of the first two phenocrysts is the most common; spinel phenocrysts occur only in a few units. Of the opaque phases, titanomagnetite is the dominant phase and is often accompanied by primary sulfide spherules. Secondary pyrite as fracture fillings and in voids is rare in the upper part of the hole; it becomes more abundant in the lower part.

With respect to the chemical-alteration parameters of basalts (Emmermann and Puchelt, 1980), the samples range from fresh to altered in the upper part of the hole $\left(\mathrm{K}_{2} \mathrm{O}=0.01-0.46 \% ; \mathrm{H}_{2} \mathrm{O}^{+}=0.39-2.56 \% ; \mathrm{CO}_{2}=0.08-\right.$ $0.46 \%$ ). In the lower part of the hole only $\mathrm{H}_{2} \mathrm{O}^{+}$increases with alteration $(0.39-2.6 \%)$, whereas $\mathrm{K}_{2} \mathrm{O}$ remains in the range of fresh basalts $(0.01-0.07 \%$; Hubberten et al., this volume; Honnorez et al., this volume). For detailed geochemical description, see Hubberten et al. (this volume).

About 150 samples from Hole 504B were selected for determination of sulfur content and isotopic composition; low amounts of sulfur prevented sulfur-isotope measurements in numerous samples.

\section{ANALYTICAL PROCEDURE}

The samples were cleaned with distilled water and crushed. Pyrite was separated by hand-picking under the binocular microscope, then the samples were fine-milled to $<200$-mesh for analysis.

The total sulfur content of the samples was determined with a "Ströhlein Coulomat 701" by combustion of the samples in an oxygen flow, followed by coulometric titration of the sulfur dioxide by a procedure modified (Erzinger, pers. comm.) after Lange and Brumsack (1977). The reproducibility of these determinations is better than $\pm 15 \%$.

Sample preparation for the sulfur-isotope determinations was carried out according to the method described by Puchelt and Hubberten (1980). With this two-step procedure, sulfides such as pyrrohotite, chalcopyrite, or other sulfides of the $\mathrm{Fe}-\mathrm{Cu}-(\mathrm{Ni})-\mathrm{S}$ system are first decomposed by treatment with hydrochloric acid in the presence of aluminum. Pyrite is not attacked in this step. In the second step, the remaining sulfur species (sulfate and pyrite) are disintegrated with a reducing acid mixture (Thode et al., 1961). The sulfur obtained by this step is termed "pyrite-sulfate" sulfur throughout this paper with quotation marks, indicating that it is a mixture of pyrite sulfur and sulfate sulfur. The sulfur is expelled as $\mathrm{H}_{2} \mathrm{~S}$, which is subsequently precipitated as CdS. This compound is reacted to form the measuring gas $\mathrm{SO}_{2}$ for mass spectrometric determinations (Ricke, 1964).

The ratio measurements were conducted on a VG-Micromass 1202 $\mathrm{S}$ mass spectrometer. The total error (preparation and measurement) of these determinations is less than $\pm 0.2 \%$ for samples of normal sizes; it can reach $\pm 1 \%$ for undersized samples.

The results are given in the usual $\delta$-notation with respect to the Cañon Diablo standard.

\section{RESULTS}

The results of the sulfur-content determinations and the isotope measurements are given in Table 1 and are shown as a function of depth in Figure 1. The sulfur-iso- tope distribution in the oxidative and in the non-oxidative part of the hole is shown as a frequency distribution in Figure 2. The sulfur content covers a broad range, from 75 to $1200 \mathrm{ppm}$, with generally lower values in the upper part of the hole. The isotopic composition of sulfide sulfur varies between -4.7 and $+3.6 \%$; most of the samples range between -1 and $+1 \%$. A slight shift from samples depleted in ${ }^{34} \mathrm{~S}$ in the oxidized part of the hole (mean value of 18 samples $=-0.26 \%$ ) to slightly enriched samples in the lower, non-oxidative part (mean of 45 samples $=+0.12 \%$ ) can be observed. The pyrite and sulfate fraction, which is not soluble in the first preparation step, shows $\delta^{34} \mathrm{~S}$ values between -4.8 and $+10.3 \%$. The observed wide spread of the values in the oxidative part of the hole (mean of 17 samples = $+3.5 \%$ ) seems to shrink in the lower part (mean of 37 samples $=+4.9 \%$ ). Nine isolated pyrites from the lower part of the hole show $\delta^{34} \mathrm{~S}$ values between -8.1 and $+5.8 \%$; seven of them range between -1.6 and $+0.9 \%$.

One separated anhydrite crystal from the lower part of the hole has a $\delta^{34} \mathrm{~S}$ value of $+33.7 \%$.

\section{DISCUSSION}

\section{Sulfur Content}

As shown in Figure 1, the sulfur content of the basalts from Hole 404B is highly variable and often depleted compared with the usual content in fresh deepsea basalt glasses (900-1200 ppm; Mathez, 1976). This depletion in sulfur can be the result of two processes:

1) According to Moore and Fabbi (1971), the interiors of pillows are depleted in sulfur relative to their rims, the sulfur possibly having escaped along cooling fractures. (A minimal amount of material is required for sulfur-isotope determinations; therefore, I never selected samples from the [rare] glassy margins, i.e., the samples with the highest sulfur content.)

2) During the low-temperature oxidative alteration of basalts, igneous sulfides are oxidized to sulfate, and sulfur may be removed almost completely from the system. Under conditions of limited oxidation, unstable sulfur compounds such as $\mathrm{SO}_{3}{ }^{2-}$ and $\mathrm{S}_{2} \mathrm{O}_{6}{ }^{2-}$ will be formed during the dissolution of igneous sulfides. The decomposition of these compounds through disproportionation may result in the formation of pyrite and the generation of $\mathrm{SO}_{4}{ }^{2-}$, which will be removed (Granger and Warren, 1969; Andrews, 1979).

\section{Upper Part of Hole 504B}

In the upper part of the hole, where oxidative alteration predominates, most of the samples are depleted in sulfur to values below $500 \mathrm{ppm}$, except in an intermediate zone between 540 and 585 meters below sea floor, where both low and high sulfur values occur. To show the relationship between the sulfur content and the degree of oxidation, the sulfur content is plotted in Figure 3 as a function of $\mathrm{Fe}_{2} \mathrm{O}_{3} /\left(\mathrm{FeO}+\mathrm{Fe}_{2} \mathrm{O}_{3}\right)$. In spite of some variation, there is a distinct inverse relation between the degree of oxidation and the sulfur content in the oxidative part of the hole (Fig. 3A): the higher the degree of oxidation, the lower the sulfur content. Only one sample has a sulfur content below $300 \mathrm{ppm}$ at 
Table 1. Sulfur isotopes, total sulfur, and degree of oxidation of basalt samples from Hole 504B.

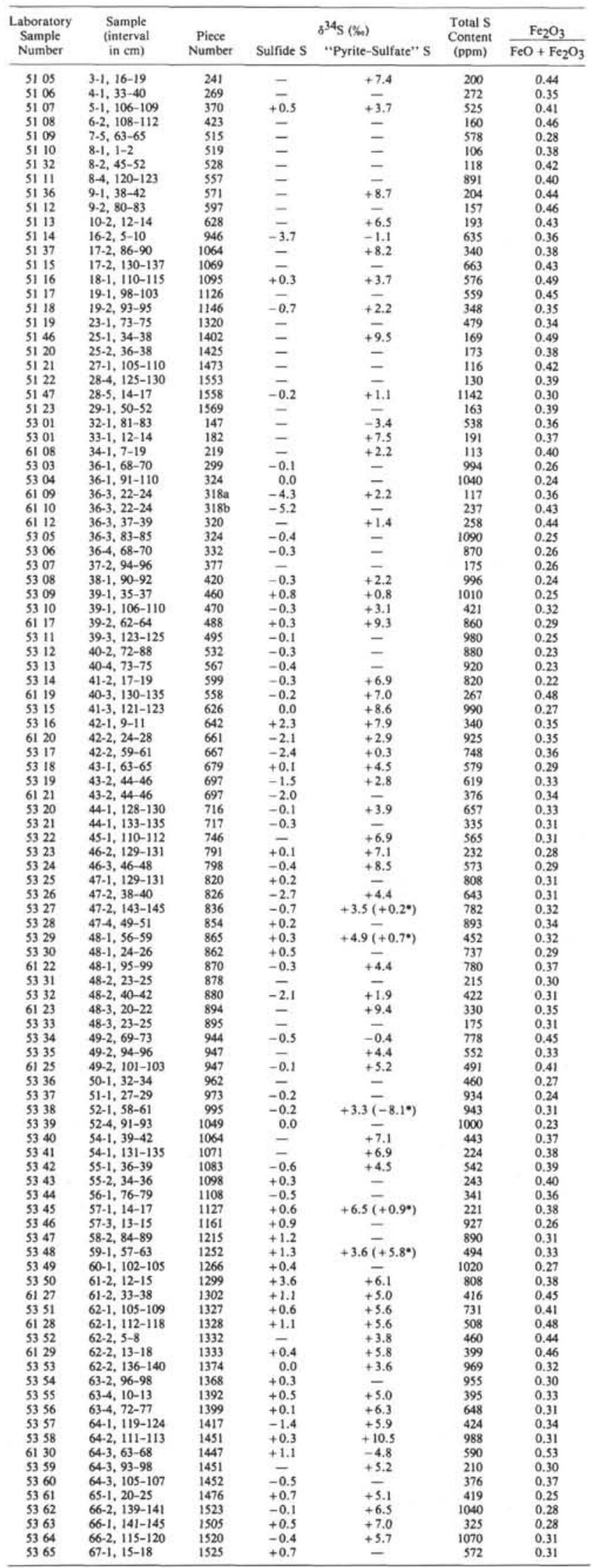

Table 1. (Continued).

\begin{tabular}{|c|c|c|c|c|c|c|}
\hline \multirow{2}{*}{$\begin{array}{l}\text { Laboratory } \\
\text { Sample } \\
\text { Number }\end{array}$} & \multirow{2}{*}{$\begin{array}{l}\text { Sample } \\
\text { (interval } \\
\text { in } \mathrm{cm} \text { ) }\end{array}$} & \multirow{2}{*}{$\begin{array}{c}\text { Piece } \\
\text { Number }\end{array}$} & \multicolumn{2}{|r|}{$\delta^{34} \mathrm{~S}(\%)$} & \multirow{2}{*}{$\begin{array}{l}\text { Total S } \\
\text { Content } \\
(\mathrm{ppm})\end{array}$} & \multirow{2}{*}{$\frac{\mathrm{Fe}_{2} \mathrm{O}_{3}}{\mathrm{FeO}+\mathrm{Fe}_{2} \mathrm{O}_{3}}$} \\
\hline & & & Sulfide $\mathrm{S}$ & "Pyrite-Sulfate" S & & \\
\hline 5366 & $68-1,102-104$ & 1538 & -4.2 & $-0.4\left(\begin{array}{l}\left(-1.2^{*}\right) \\
\left(-1.6^{*}\right)\end{array}\right.$ & 772 & 0.31 \\
\hline 5367 & $69-1,57-59$ & 1543 & +1.6 & $\begin{array}{l}-2.6 \\
-6\end{array}$ & 843 & 0.39 \\
\hline 5368 & $69-1,69-73$ & 1544 & -0.4 & +3.9 & 411 & 0.39 \\
\hline 5369 & $70-1,99-100$ & 1559 & +1.6 & +2.6 & 768 & 0.32 \\
\hline 6133 & $70-2,0-3$ & 1563 & +0.6 & +3.9 & 553 & 0.37 \\
\hline 5370 & $70-2,12-16$ & 1564 & -0.4 & +6.4 & 1070 & 0.32 \\
\hline 5371 & $64-1,132-136$ & 1419 & +0.5 & $+6.0\left(-1.5^{*}\right)$ & 656 & 0.33 \\
\hline 5372 & $58.3,0-150$ & (washings) & - & $\left(-1.0^{*}\right)$ & - & - \\
\hline 6135 & $48-3,20-22$ & 894 & - & $+33.8 *{ }^{\prime}$ & - & - \\
\hline
\end{tabular}

- Pure pyrites separated under the binocular microscope.

* Separated anhydrite crystal.

$\mathrm{Fe}_{2} \mathrm{O}_{3} /\left(\mathrm{Fe}_{2} \mathrm{O}_{3}+\mathrm{FeO}\right)$ ratios of less than 0.35 ; only one sample has more than $800 \mathrm{ppm} \mathrm{S}$ above a value of 0.35 . It is obvious that in this part of the hole low-temperature sea-water alteration occurred under conditions sufficiently oxidizing to form sulfate from the dissolution of igneous sulfides. This sulfate has been removed subsequently from the system. Because secondary pyrite is absent or rare in this part of the column, in most cases the amount of circulating sea water must have been sufficient to avoid the formation of unstable sulfur species such as sulfite or thiosulfate, which could have disproportionated to form pyrite.

\section{Lower Part of Hole 504B}

The behavior of sulfur in the lower part of the hole is different than in the upper part. Whereas many samples have higher values comparable to fresh sulfur-saturated basalts, others show a depletion in sulfur as in the upper part. As illustrated by the alteration minerals observed in this part of the hole (Honnorez et al., this volume), the intensity of alteration is as high as in the upper part, but the type of alteration is different. Pyrite becomes a dominant alteration phase; thus, the higher amounts of sulfur are not a result of "fresher" conditions, but a result of the appearance of secondary pyrite. During alteration of the basalts, the sulfur has been extracted from primary igneous sulfides and precipitated as pyrite under limited-oxidation conditions (cf. Granger and Warren, 1969).

The relation of the sulfur content to the ratio of $\mathrm{Fe}_{2} \mathrm{O}_{3} /\left(\mathrm{Fe}_{2} \mathrm{O}_{3}+\mathrm{FeO}\right)$ is different from the relation in the upper part of the hole. Many of the samples show a low sulfur content at a ratio of less than 0.35 , whereas in the range above 0.42 the sulfur content is higher than $300 \mathrm{ppm}$. This possibly indicates that in the early history of these basalts-before they were deeply buried by sediments, or even by the uppermost basalts-the alteration fluid was oxidizing (i.e., it was normal sea water). Reducing conditions followed as the basalts came to a greater depth and were sealed from sea water by overlying more-massive units. Samples with lower sulfur content therefore could have lost their sulfur during oxidative sea-water alteration, at least in some of the more-fractured units in this lower part of the sequence; the degree of oxidation as illustrated by the ratio $\mathrm{Fe}_{2} \mathrm{O}_{3}$ / $\left(\mathrm{Fe}_{2} \mathrm{O}_{3}+\mathrm{FeO}\right)$ has changed after this early state to lower ratios because of the reducing character of hydrothermal solutions. 


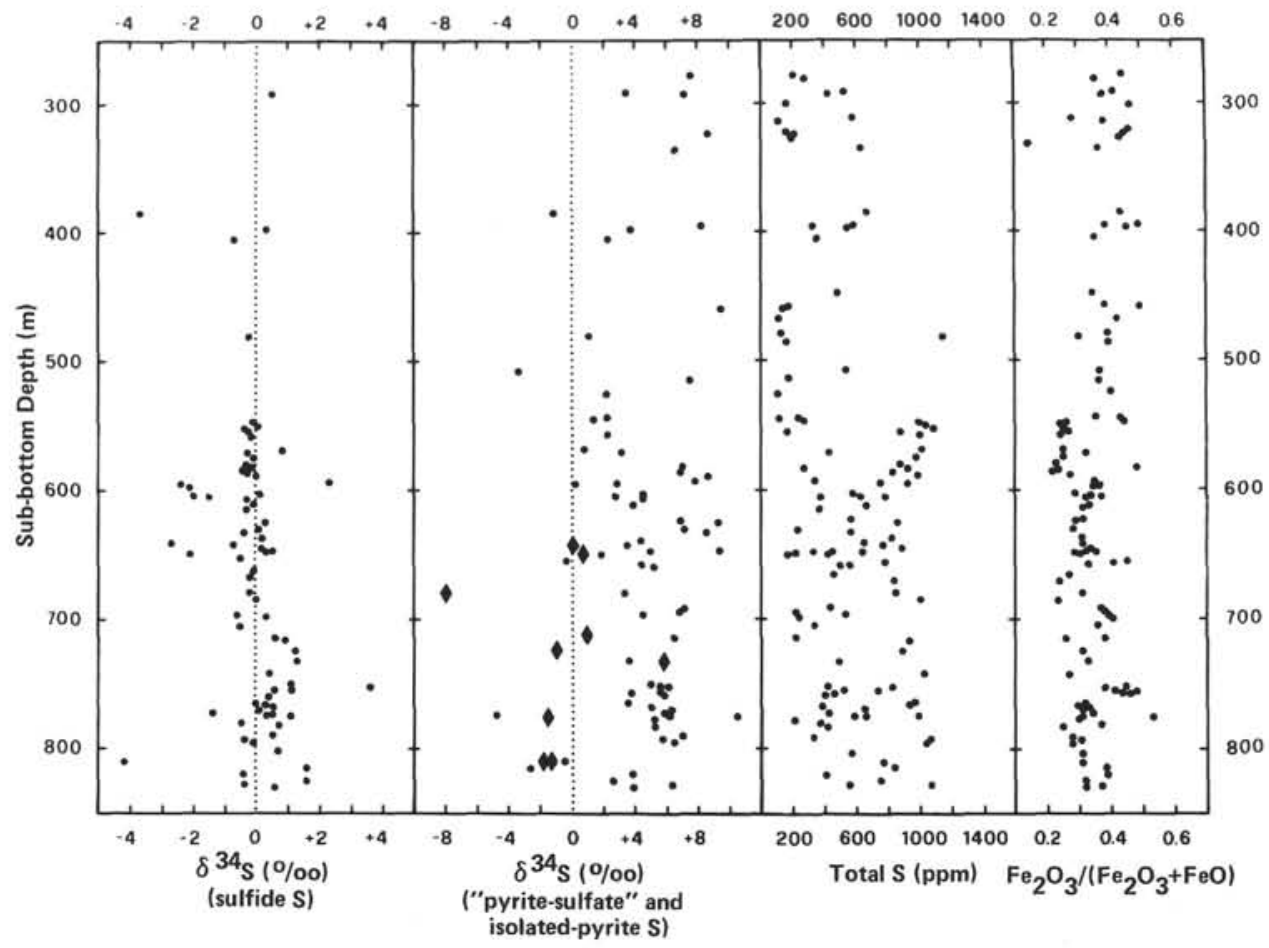

Figure 1. Sulfur isotopes (sulfide sulfur, first column; "pyrite-sulfate" sulfur and isolated pyrite sulfur [diamonds], second column), total sulfur content, and degree of oxidation-expressed as $\mathrm{Fe}_{2} \mathrm{O}_{3} /\left(\mathrm{Fe}_{2} \mathrm{O}_{3}\right.$ $+\mathrm{FeO}$ ) - as a function of depth of Hole 504B.
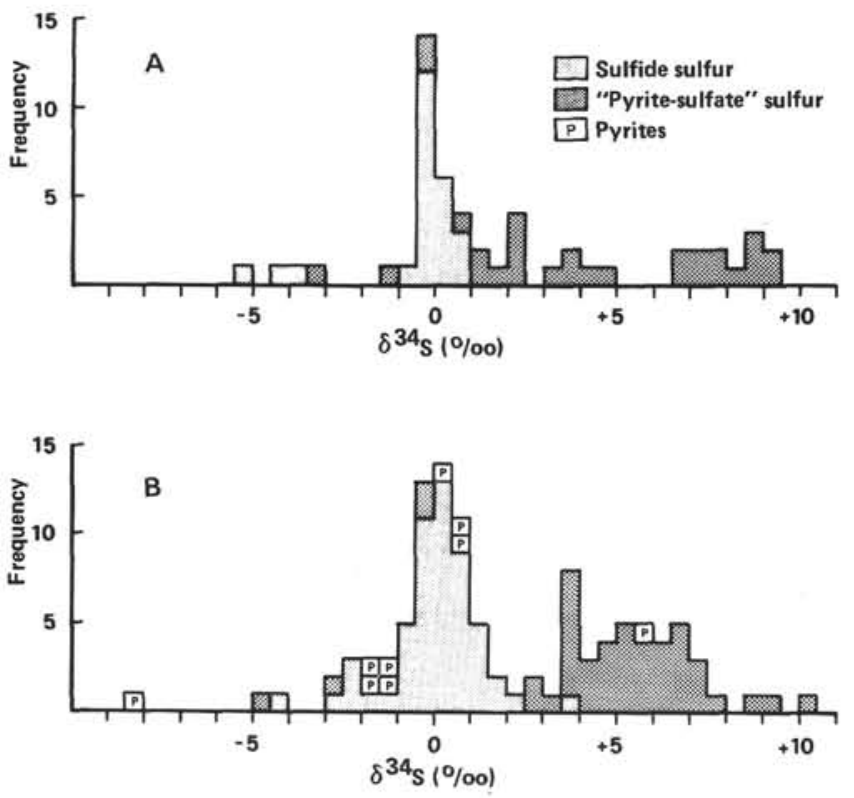

Figure 2. A. Frequency distribution of the isotope ratios of sulfide sulfur, "pyrite-sulfate" sulfur, and pyrites in the upper, oxidative part of Hole 504B. B. Similar frequency distribution for the lower, non-oxidative part below 590 meters sub-bottom depth.

\section{Sulfur-Isotope Composition}

\section{Sulfide Sulfur}

The isotopic composition of sulfide sulfur, representing primary igneous sulfides, shows some variations around the zero value of the $\delta$ scale. Although most of the samples vary only slightly (from -0.5 to $+1 \%$ ), others are enriched (up to $+3.6 \%$ ) or depleted (up to $-4.7 \%$ ) in ${ }^{34} \mathrm{~S}$ compared to the overall mean $(-0.01 \%)$. Some differences between the upper oxidizing part and the lower reducing part are obvious in down-hole variations of the sulfur isotopes (Fig. 1).

\section{Upper Part of Hole 504B}

Except for one sample with a value of $-3.9 \%$, samples in the upper part lie in a very narrow range between -0.7 and $+0.8 \%$. Unfortunately, the sulfide-sulfur content of most of the samples from Leg 69 is too low to be analyzed for sulfur isotopes. As shown in Figure 1, most of the samples representing the oxidized part of Hole 504B were taken from a section between 540 and 585 meters, which is intermediate in sulfur content and possibly not typical of the oxidized part. The intermediate character of this zone between oxidizing and reducing is seen in the behavior of strontium and oxygen isotopes (Barrett, this volume). Nevertheless, the isotope ratios of the sulfides from Hole 504B above 585 meters represent values typical of oceanic tholeiites, with a mean of $-0.26 \%$ ( 18 samples).

\section{Lower Part of Hole 504B}

As shown in Figures 1 and 2, the sulfur-isotope composition in the $\mathrm{HCl}$-soluble sulfides is somewhat different in the lower part of the hole. More samples deviate from the meteoritic value; the mean $\left(\delta^{34} \mathrm{~S}=\right.$ $+0.12 \%$; 45 samples) is shifted slightly towards heavier 

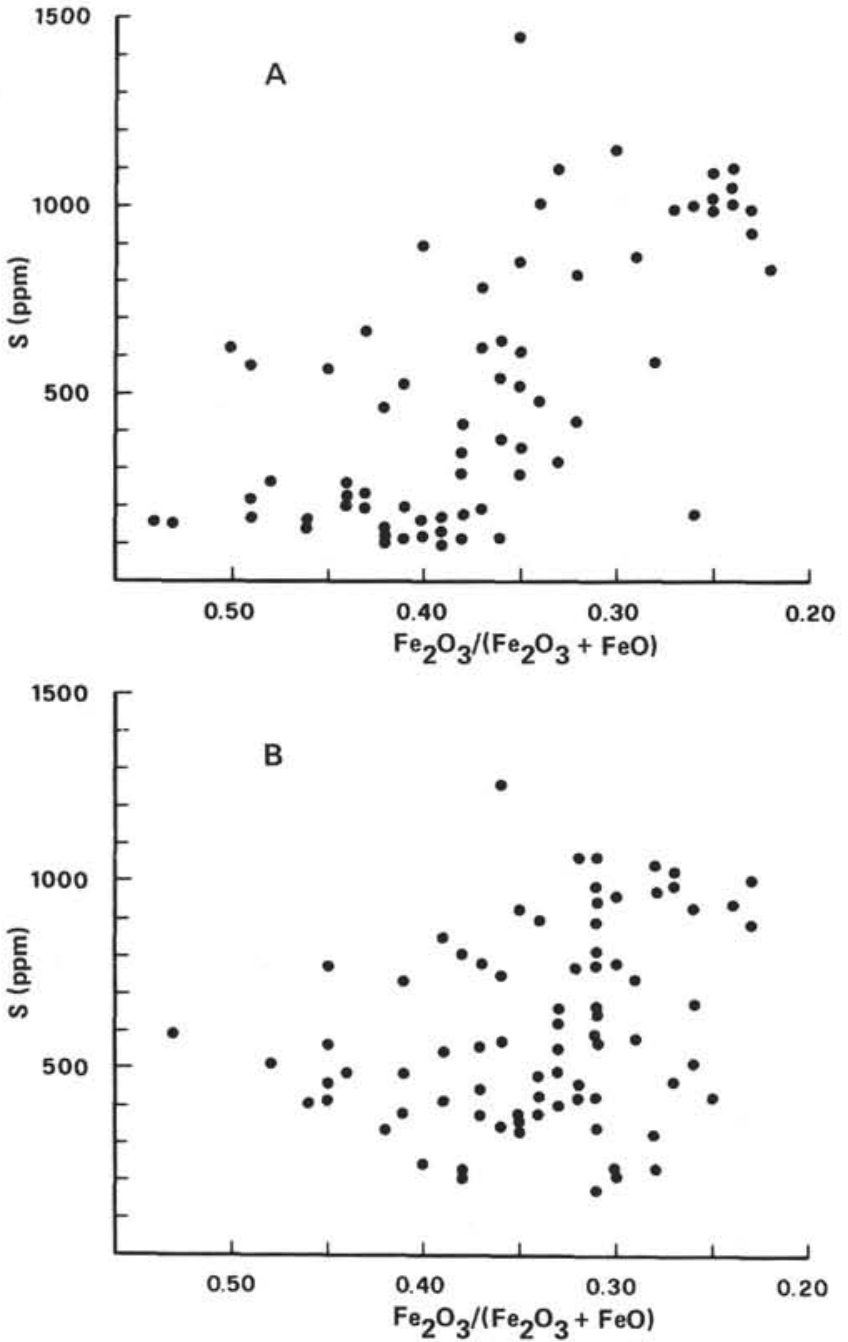

Figure 3. A. Total sulfur content versus $\mathrm{Fe}_{2} \mathrm{O}_{3} /\left(\mathrm{Fe}_{2} \mathrm{O}_{3}+\mathrm{FeO}\right)$ for samples from the upper part of Hole 504B. B. Similar plot for samples from the lower part of Hole 504B.

isotope ratios. The isotopic composition of primary sulfides may change because of (1) processes attending magmatic fractionation, (2) quenching during eruption of the lavas, or (3) alteration of the rocks. Isotope fractionation resulting in the enrichment in the heavier isotope, ${ }^{34} \mathrm{~S}$, as observed for more-developed basalts (Schneider, 1970), is not important in the case of the chemically and petrologically rather uniform tholeiites from Hole 504B (Hubberten et al., this volume). During the quenching of erupting lavas, the interiors of pillows can be depleted in sulfur compared to their rims, because of diffusion (Moore and Fabbi, 1971). Kinetic isotope effects could result in a slight enrichment of ${ }^{34} \mathrm{~S}$ in the sulfur-depleted parts of a pillow or a thin flow. If such effects were important, they should not be restricted to the lower part of the hole and should occur also in the upper part. Furthermore, an enrichment in ${ }^{34} \mathrm{~S}$ is observed also in parts of massive basalt units where kinetic effects of diffusion should not occur. Nevertheless, slight variations in $\delta^{34} \mathrm{~S}$ in both parts of Hole 504B may be explained by such processes.
Because the larger spread of values is concentrated in the lower part of the hole, it seems obvious that the reducing alteration conditions are responsible for these values. If, during the dissolution of primary sulfides, kinetic effects cause a depletion of ${ }^{32} \mathrm{~S}$ in the remaining sulfide, these sulfides will be isotopically heavier.

Another probable explanation, however, may be found in the preparation technique for sulfide sulfur. As described earlier, all sulfides soluble in hydrochloric acid are disintegrated in this step. In fresh basalts, these sulfides always represent primary igneous phases, whereas in altered basalts, besides pyrite, which is in most cases the only secondary sulfide, other sulfides, such as marcasite or chalcopyrite, may occur in secondary phases (Humphris et al., 1980; Pertsev and Rusinov, 1980). These sulfides may shift the isotopic composition of the primary sulfides.

Despite these variations, the sulfur-isotope composition of the assumed mantle sulfur is reflected in the sulfur-isotope composition of the primary sulfides in the lower part of the hole. Figure 4 shows a comparison of sulfur-isotope data from various regions (data sources: continental tholeiites and alkali olivine basalts, Schneider [1970]; Bermuda Rise, Puchelt and Hubberten [1980]; part of Galapagos Rift and East Pacific Rise, Hubberten and Puchelt [1980]; Galapagos Rift, Hubberten [in press]; Saudi Arabia and most parts of the East Pacific Rise, Hubberten (unpubl. data). The sulfur-isotope ratios for sulfide sulfur of all investigated tholeiites-oceanic or terrestrial-fall in a very narrow range between -0.4 and $0 \%$. Only the basalts from the reduced part of Hole 504B fall in the positive part of the $\delta$ scale for sulfide sulfur.

On the basis of the analysis of three abyssal tholeiites from the Mid-Atlantic Ridge, Kanehira et al. (1973) argued for a slightly ${ }^{34}$ S-enriched sulfur-isotope composition of mantle sulfur. Using the data presented in Figure 4 , I propose a slightly negative sulfur-isotope value for typical oceanic tholeiites, independent of their provenance. Enrichment in ${ }^{34} \mathrm{~S}$ probably will occur in more-

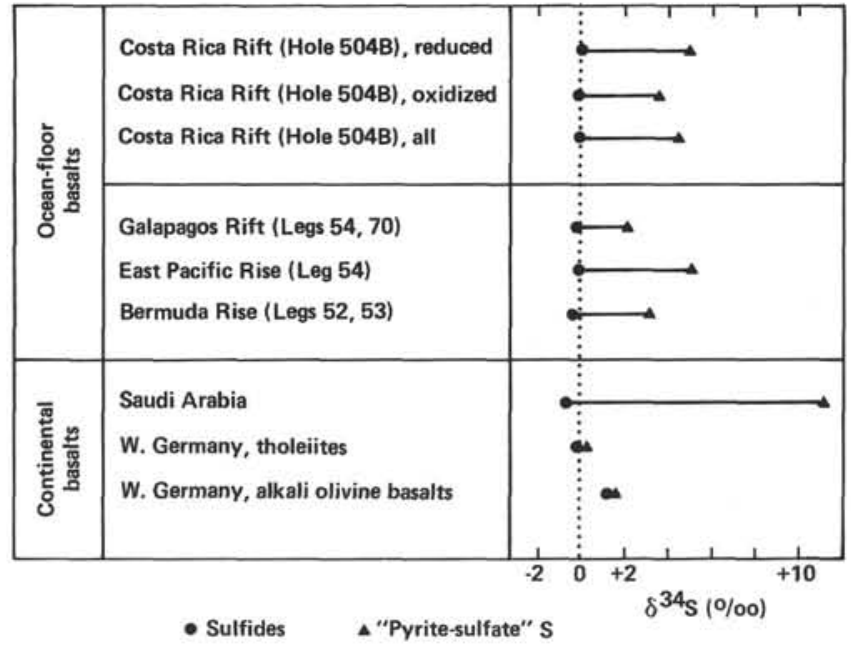

Figure 4. Mean values of $\delta^{34} \mathrm{~S}$ for continental and oceanic basalts from various regions (for data sources, see text). 
fractionated rocks (Wedepohl and Muramatsu, 1979; Hubberten and Puchelt, 1980), as shown, for example, for alkaline olivine basalts by Schneider (1970). The slight enrichment in ${ }^{34} \mathrm{~S}$ observed in the lower part of Hole 504B must be due to secondary influences attending alteration of the basalts, because they are neither alkalic basalts nor fractionated tholeiites.

\section{"Pyrite-Sulfate" Sulfur}

In the second preparation step, any secondary pyrites and sulfates were disintegrated-hence the term "pyrite-sulfate" fraction. This fraction is more sensitive to secondary influences, such as pyrite formation or addition of sea-water-derived sulfate. The secondary processes can easily overprint the primary sulfate that occurs in traces in basalts (Schneider, 1970), because of the amount of sulfur introduced to the system.

As shown for the sulfide-sulfur fraction, differences between the upper and the lower part of the hole also exist for the "pyrite-sulfate" fraction. These differences in the isotopic composition are visible mineralogically in the presence of pyrite as a dominant opaque phase in the lower part and the relatively rare occurrence of this sulfide in the upper part of the hole. In addition to pyrite, anhydrite was found in a single occurrence at a depth of 640 meters as another secondary sulfur-bearing mineral (Honnorez et al., this volume).

\section{Upper Part of Hole 504B}

At the temperatures of basalt solidification, sulfate sulfur in isotopic equilibrium with sulfide sulfur theoretically should give $\delta^{34}$ S values between +2 and $+4 \%$ o (Sakai, 1957). In some of the investigated samples from this part of the hole, the "pyrite-sulfate" sulfur lies in this range and therefore could represent primary sulfate. Most of the samples are more or less enriched in ${ }^{34} \mathrm{~S}$ compared to the theoretical value, which indicates secondary influences, such as addition of sea-water sulfate or formation of secondary pyrite.

The isotope values of the "pyrite-sulfate" sulfur seem to be concentrated within two ranges: one from +1 to $+5 \%$, the other from +6.5 to $+9.5 \%$ (Fig. 2). Because pyrite is rare in this part of the hole, the ${ }^{34}$ S-enriched "pyrite-sulfate"' sulfur may be the result of addition of sea-water sulfate during alteration. The absence of pyrite in most of the samples indicates alteration under oxidizing conditions that prevented formation of pyrite through disproportionation of sulfite or thiosulfate formed by the dissolution of primary sulfides. Some rare pyrites from this part of the hole with values from -0.2 to $-18.3 \%$ o (Belyi et al., this volume), indicate bacterial reduction of sulfate. The activity of bacteria may be responsible for part of the high "pyrite-sulfate" values as a result of relative enrichment in ${ }^{34} \mathrm{~S}$ in the remaining sulfate. Because organic carbon is required for bacterial reduction of sulfate, this process must have happened under near-surface conditions before the basalts were covered by newly erupting lavas.

\section{Lower Part of Hole 504B}

In contrast, the "pyrite-sulfate", sulfur in the lower part of the hole is concentrated around a mean of $+5 \%$, showing a maximum between +3.5 and $+4 \%$; many samples range around $+6 \%$. Because pyrite is abundant in this part of the hole, it seems obvious that this mineral is the main constituent of the "pyrite-sulfate"' fraction; however, the istopic composition of isolated pyrites is in most cases close to the zero value of the $\delta$ scale, or even slightly depleted in ${ }^{34} \mathrm{~S}$ compared to the sulfide sulfur (Fig. 2).

About 20 separated pyrites isotopically analyzed by Belyi et al. (this volume) mostly fall in the negative part of the scale; only one analyzed pyrite sample plots in the range of the "pyrite-sulfate" fraction $(+5.8 \% 0)$. It seems possible that pyrites formed by disproportionation of thiosulfate or sulfite-themselves formed by the dissolution of primary sulfides (Andrews, 1979) under reducing or only weakly oxidizing conditions-show values as determined for the isolated pyrites; however, because of changing $\mathrm{Eh}$ or $\mathrm{pH}$ conditions, part of the pyrites responsible for the isotope ratios in the "pyritesulfate" fraction may be shifted to the heavier side of the $\delta$ scale (Ohmoto, 1972).

Another explanation for the heavier sulfur-isotope values in the "pyrite-sulfate" fraction is the possible presence of sulfates in trace amounts. Sulfates are represented by anhydrite in a single sample $\left(\delta^{34} \mathrm{~S}=+33.7 \%\right.$ )

The relatively narrow range of the sulfur-isotope ratios in the "pyrite-sulfate" fraction is, however, indicative of a homogeneous source. Rather constant Eh and $\mathrm{pH}$ conditions or the addition of sulfur by circulating hydrothermal solutions are required.

\section{CONCLUSIONS}

The sulfur content and sulfur-isotope compositions of basalts are significantly different for the upper (oxidative) part of Hole 504B compared to the lower (nonoxidative or only weakly oxidative) part of this hole. These differences are mineralogically reflected by the presence of pyrite in the lower part and its absence in the upper part of the hole.

The sulfur content in the upper part is significantly lower $(<600 \mathrm{ppm})$, because of dissolution of igneous sulfides under highly oxidizing conditions and the almost complete removal of sulfate from the system. In the lower part of the hole, the sulfur content is mostly in the range of fresh sulfur-saturated tholeiites (up to 1100 ppm) but is as low as 200 ppm. During the dissolution of primary sulfides under weakly oxidizing conditions, sulfur was precipitated as pyrite; additional sulfur may have been introduced by circulating hydrothermal solutions.

The isotopic composition of the igneous sulfides (mean $=-0.01 \%$ ) reflects the assumed isotopic composition of mantle sulfur; slightly higher values in the lower part of the hole are probably the result of secondary influences. The "pyrite-sulfate" fraction is very sensitive to secondary processes attending alteration of the basalts. In the upper part of the hole, the isotope values are mainly controlled by addition of sea-water sulfate and by bacterial reduction of sulfate at the basalt/sediment interface. In the lower part of the hole, precipitation of pyrite as a result of dissolution of primary sulfides produces sulfur-isotope values from -8.1 to $+5.8 \%$, depending on the $\mathrm{Eh}$ and $\mathrm{pH}$ of the solution; 
higher values may be due to an admixture of heavy sulfate (one anhydrite, $\delta^{34} \mathrm{~S}=+33.7 \%$ ) , or to an addition of heavier sulfur from circulating hydrothermal solutions.

\section{ACKNOWLEDGMENTS}

This investigation was supported by a grant of the Deutsche Forschungsgemeinschaft, Bonn. The manuscript was critically reviewed by Prof. Dr. J. Hoefs (Göttingen) and Prof. Dr. H. Puchelt (Karlsruhe), who made valuable suggestions; Dr. D. E. Large (Braunschweig) improved the English text. Dr. J. Erzinger and Miss A. Haas carried out the sulfur-content determinations; Mrs. E. Weiher was of much assistance in preparing the samples for isotope measurements.

I want to thank all individuals and institutions who helped in the investigations and preparation of this paper.

\section{REFERENCES}

Andrews, A. J., 1979. On the effect of low temperature seawater-basalt interaction on the distribution of sulfur in oceanic crust, layer 2. Earth Planet. Sci. Lett., 46:68-80.

CRRUST, in press. Geothermal regimes of the Costa Rica Rift, East Pacific, investigated by Drilling DSDP-IPOD Legs 68, 69 and 70. Geol. Soc. Am. Bull.

Czamanske, G. K., and Moore, J. G., 1977. Composition and phase chemistry of sulfide globules in basalts from the Mid-Atlantic Ridge rift valley near $37^{\circ} \mathrm{N}$ lat. Geol. Soc. Am. Bull., 88:587-599.

Emmermann, R., and Puchelt, H., 1980. Major and trace element chemistry of basalts from Holes 417D and 418A, Deep Sea Drilling Project Legs 51-53. In Donnelly, T., Francheteau, J., Bryan, W., Robinson, P., Flower, M., Salisbury, M., et al., Init. Repts. DSDP, 51, 52, 53, Pt. 2: Washington (U.S. Govt. Printing Office), 987-1000.

Granger, H. C., and Warren, C. G., 1969. Unstable sulfur compounds and the origin of roll-type uranium deposits. Econ. Geol., 64: 160-171.

Grinenko, V. A., Dmitriev, L. V., Migdisov, A. A., and Sharas'kin, A. Ya. 1975. Sulfur content and isotope composition for igneous and metamorphic rocks from mid-ocean ridges. Geochem. Internat., 12:132-137.

Hubberten, H.-W., in press. Sulfur and sulfur isotope content of basalts from the Galapagos Rift (DSDP Legs 54 and 70). In Honnorez, J., Von Herzen, R., et al., Init. Repts. DSDP, 70: Washington (U.S. Govt. Printing Office).

Hubberten, H.-W., and Puchelt, H., 1980. Zur Schwefelisotopengeochemie basaltischer Gesteine. ZFI Mitt., 30:80-90.
Humphris, S. E., Thompson, R. N., and Mariner, G. F., 1980. The mineralogy and geochemistry of basalt weathering, Holes 417A and 418A. In Donnelly, T., Francheteau, J., Bryan, W., Robinson, P., Flower, M., Salisbury, M., et al., Init. Repts. DSDP, 51, 52, 53, Pt. 2: Washington (U.S. Govt. Printing Office), 1201-1217.

Kanehira, K., Yui, S., Sakai, H., and Sasaki, A., 1973. Sulphide globules and sulphur isotope ratios in the abyssal tholeiite from the Mid-Atlantic Ridge near $30^{\circ} \mathrm{N}$ lat. Geochem. J., 7:89-96.

Lange, J., and Brumsack, H.-J., 1977. Total sulphur analysis in geological and biological materials by coulometric titration following combustion. Analyt. Chem., 286:361-366.

Mathez, E. A., 1976. Sulfur solubility and magmatic sulfides in submarine basalt glass. J. Geophys. Res., 81:4269-4276.

Moore, J. G., and Fabbi, B. F., 1971. An estimate of the juvenile sulfur content of basalts. Contr. Mineral. Petrol., 41:105-118.

Ohmoto, H., 1972. Systematics of sulfur and carbon isotopes in hydrothermal deposits. Econ. Geol., 67:551-578.

Pertsev, N. N., and Rusinov, V. L., 1980. Mineral assemblages and processes of alteration in basalts at Deep Sea Drilling Project Sites 417 and 418. In Donnelly, T., Francheteau, J., Bryan, W., Robinson, P., Flower, M., Salisbury, M., et al., Init. Repts. DSDP, 51, 52, 53, Pt. 2: Washington (U.S. Govt. Printing Office), 1219-1242.

Puchelt, H., and Hubberten, H.-W., 1980. Preliminary results of sulfur isotope investigations on Deep Sea Drilling Project cores from Legs 52 and 53. In Donnelly, T., Francheteau, J., Bryan, W., Robinson, P., Flower, M., Salisbury, M., et al., Init. Repts. DSDP , 51, 52, 53, Pt. 2: Washington (U.S. Govt. Printing Office), $1145-1148$.

Ricke, W., 1964. Präparation von Schwefeldioxid zur massenspektrometrischen Bestimmung des Schwefel-Isotopen-Verhältnisses ${ }^{32} \mathrm{~S} /$ ${ }^{34} \mathrm{~S}$ in natürlichen Schwefelverbindungen. Z. Anal. Chem., 199: 401-413.

Sakai, H., 1957. Fractionation of sulfur isotopes in nature. Geochim. Cosmochim. Acta, 12:150-169.

Sakai, H., Ueda, A., and Field, C. W., 1978. $\delta^{34}$ S and concentration of sulfide and sulfate sulfurs in some ocean-floor basalts and serpentinites. Short Papers of the Fourth Internat. Conf. Geochem. Cosmochem. Isotope Geol., 372-374.

Schneider, A., 1970. The sulfur isotope composition of basaltic rocks. Contrib. Mineral. Petrol., 25:95-124.

Thode, H. G., Monster, J., and Dunford, H. B., 1961. Sulfur isotope geochemistry. Geochim. Cosmochim. Acta, 25:159-174.

Wedepohl, K. H., and Muramatsu, Y., 1979. The chemical composition of kimberlites compared with the average composition of three basaltic magma types. Proc. Second Internat. Kimberlite Conf., 1:300-312. 